\title{
"IT IS A NOMOS VERY DIFFERENT FROM THE LAW": ON ANARCHY AND THE LAW
}

\begin{abstract}
The relationship between anarchy and the law is, to say the least, an uncomfortable one. The so-called 'classical' anarchist position - in all its heterogeneous tendencies - is, usually, characterised by a total opposition against the law. However and despite its invaluable contribution and the ever-pertinent critique of the state of affairs, this 'classical' anarchist position needs to be re-examined and rearticulated if it is to pose an effective nuisance to the current (and much complex) mechanisms of domination and the oppression of dogmatism and dominance of the law. Taking into account the aforementioned challenges, in this article, I examine and develop two notions of the philosophical thought of Gilles Deleuze, namely that of the institution and that of the nomos of the nomads. In doing so, I aim to think anew the relationship between anarchy and the law and, ultimately, to point towards an ethico-political account, of what I shall call an an-archic nomos which escapes (or, at least, tries to) the dogmatism and "archist" mentality of the law.
\end{abstract}

Keywords: Anarchy, law, nomos, institutions, Deleuze.

\section{„JEST TO NOMOS BARDZO RÓŻNY OD PRAWA": O ANARCHII I PRAWIE}

Streszczenie. Relacja pomiędzy anarchią a prawem jest, delikatnie mówiąc, niewygodna. Tak zwane „klasyczne” stanowisko anarchistyczne - we wszystkich jego heterogenicznych tendencjach - charakteryzuje się zazwyczaj całkowitym sprzeciwem wobec prawa. Jednakże, pomimo swojego nieocenionego wkładu i nieustannie aktualnej krytyki stanu rzeczy, ta „klasyczna” pozycja anarchistyczna musi zostać ponownie zbadana i ponownie wyartykułowana, jeśli ma stanowić skuteczną przeszkodę dla obecnych (i bardzo złożonych) mechanizmów dominacji i opresji dogmatyzmu i dominacji prawa. Biorąc pod uwagę powyższe wyzwania, w niniejszym artykule analizuję i rozwijam dwa pojęcia myśli filozoficznej Gilles'a Deleuze'a, a mianowicie pojęcie instytucji oraz pojęcie nomosu nomadów. W ten sposób chcę na nowo przemyśleć relację między anarchią a prawem i ostatecznie wskazać na etyczno-polityczne ujęcie tego, co nazywam an-archicznym nomosem, który wymyka się (lub przynajmniej próbuje) dogmatyzmowi i „archistycznej” mentalności prawa.

Słowa kluczowe: anarchia, prawo, nomos, instytucje, Deleuze.

"University of Kent; c.marneros@kent.ac.uk

I would like to thank Gian Giacomo Fusco for the support and helpful comments and edits. 
On the breaking of this cycle maintained by mythical forms of law, on the suspension of law with all the forces on which it depends as they depend on it, finally therefore on the abolition of state power, a new historical epoch is founded.

Walter Benjamin ${ }^{1}$

\section{INTRODUCTION}

If the law, but also, laws and rights more generally, are susceptible to what it could be seen as a systemic dogmatism in the sense that they can be understood as a transcendent authority that dictates and imposes hierarchising rules of and over living - in the sense of an arche [ $\alpha \rho \chi \eta ்],{ }^{2}$ that is, as a monocular prism of rightness upon a multiplicity of modes of being, acting effectively as "a limitation of actions" (Deleuze 2007, 19) - of what is possible, then we have to remain able to ask within and beyond the auspices of legal theory: is it possible to even think in terms of an an-archic (without an archē) mode of being, that is an ethos which thinks and does politics beyond the dogmatism and the commands of the law, laws and rights? Furthermore, how are we to respond to the usual protestation of (legal) authority and, especially, the view that understands the law as a universal framework of fundamental legality, and especially so when it is often admitted that it 'may not be perfect', but the law is 'the only' or 'the most socially efficient' way to be and to act?

In this article, considering the aforementioned aporias, I aim to think in terms of and point towards an ethico-political account of, what I shall call, an an-archic nomos [vó $\mu \varsigma$ ], which is influenced by, but also tries to develop further, Gilles Deleuze's understanding of the term, nomos of the nomads. Such an account aims to think beyond the law and think anew our relation with laws and rights, more generally. I should stress, however, that my intention is not to provide a definite answer, as a sort of better 'solution' to the 'problem' of legalism a 'manifesto' or 'programme'. I argue that an examination of Deleuze's understanding of nomos (and his thought more broadly) has something interesting to offer to an ethos that tries to live immanently and do politics in an an-anarchic way, which escapes

\footnotetext{
${ }^{1}$ Benjamin 1986, 300.
}

${ }^{2}$ The term arche means 'to be the origin', or to be prior to something, thus it is used here to signify the foundational principle, the beginning of everything that succeeds it. It can also have the meaning of 'a command'. It could be seen that both meanings have a close connection to a notion of the law as a dogmatic, archist principle that commands our modes of being. See: Agamben 2019. 
the dogmatism of the law, laws and rights at least in their transcendent modality. ${ }^{3}$ I should also stress that my choice to employ and to continue to use a term which is broadly understood as a juridical one, nomos in order to schematically describe my account does not suggest any sort of reconciliation of anarchic thought with the law, or any other form of recognition of an emancipatory promise, in a more 'progressive' more 'inclusive' theorisation of the law. It is rather an examination of how we can create different potentialities of life, which refuse to get captured within the dogmatism of a transcendent, moralising mode of a juridicalised being. To that extent, the use of a juridical term to signify a non-juridical ethos (or, in better terms, a non-juridicalised life) manifests a paradox and an irony which remains open to ponder on.

In what follows then, we shall start our examination by a brief exploration of the so-called blackmail of the law and the 'classical anarchist' responses to it (Section 1). Consequently, I ponder on the aforementioned modalities of such an an-archic nomos as centrally formed by two Deleuzian notions: the institution (Section 2) and the nomos of the nomads (Section 3). By placing these two notions in direct opposition to the dogmatism of the law, laws and rights, I aim to think beyond and escape the capture of the dogmatism of the archist mentality of the law.

\section{ON LAW'S BLACKMAIL AND 'CLASSICAL'ANARCHIST RESPONSES}

Law's dogmatic mentality operates with the use of a powerful blackmail. According to this blackmail, any form of criticism that points towards the overreach of law's universal framework of human values runs the risk of embracing an always-already characterised liminal situation where the absence of the law, laws or rights will signify the beginning of a much more chaotic outcome; akin to that where "the violent anarchy of the state of nature" (Newman 2012, 308), a kind of Hobbesian state of Warre, will become unstoppable and, as a result, life will become "solitary, poor, nasty, brutish and short" (Hobbes 1986, 186). This is especially pertinent when law claims

${ }^{3}$ I do not aim to argue that Deleuze himself was an anarchist and I am not interested in such mundane discussions which are trying to present an image of an author in order to serve certain political and non-political (or mere 'gossiping') purposes. I, simply, want to argue that Deleuze's thought may have something interesting to offer to the efforts to (re)think anarchy in terms of an ethos and a related politics. This is, of course, not a radically novel view, with Deleuze's relation to anarchy and his huge, direct or indirect, influence on many theorists of anarchy, anarchist group and movements being well-known. In fact, only within the last year, an edited collection on Deleuze and anarchism also a lexicon of anarchic concepts, which places Deleuze within the broader anarchist tradition were published. See respectively, Gray van Heerden and Eloff (2019) and Colson (2019). 
to operate as something akin to what Carl Schmitt saw as the formation of a Christian Empire (or what we can call a moral Empire of the West). In other

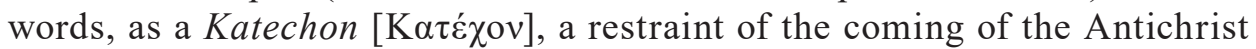
- and, we could add, the coming of an-archy (Schmitt 2006, 59-62). While this view is problematic for various reasons that are not the central subject of my interest here, it remains of relevance since this 'sense' appears to have managed to influence, to a significant extent whether explicitly or implicitly, a large proportion of theoretical scholarship on law and authority more broadly. For example, we, usually, read of an explicit or implicit established by now belief that the law and a wider notion of being governed by 'law and order', or what, the French collective of radical philosophers, Tiqqun, call 'Empire', are "the crowning achievement of a civilisation, the end-point of its ascendant arc" (Tiqqun 2010, 127) and so forth. Perhaps, it is this successful fearmongeringconsensus-building in the name of defence against a, supposed, chaotic aftermath, if anyone was to doubt the universality, effectiveness or even the particular ways in which the values of law are procured and defended, that has led critics to be careful enough to avoid unleashing a, potentially, more powerful or, as it is tellingly termed, 'total' critique that questions, for good reasons, the very notion of a mode of thought that thinks that thought itself is now only possible within this legalistic or juridical framework.

In addition, it could be further speculated that, perhaps, the dominance of arche as a modality (grounding and thus, enabling law or right on the basis of some higher law etc.) and its morality-coding have rendered any thinking otherwise an extremely difficult, if not at times institutionally impossible and unwelcome task. Such a mode of archist thinking hierarchises among and above beings and ideas and has contributed to an understanding of the law as a framework-concept above human experience, or as a value of values that - despite any flaws - represents something which can be defined as 'the good' itself or the mark of 'the civilised', once more above the level of the immanent experience of values. Nonetheless, this is beside the point ultimately, since this 'overthinking' in itself about any future potential repercussions of a life beyond the law does not have anything to say about the present and thus it tends, in itself, to be an uncreative and reactive over-investment.

Moreover, we need to ponder on the (im)possibility of thinking and using terms that are infused by a strong historical juridical sense (such as nomos), in order to point towards a non-dogmatic, an-archic ethos and way of thinking. Such a potential becomes even more difficult if we additionally consider that the relationship between the law and anarchy tends to be characterised, to say the least, as an uncomfortable one. Taking a purely negative approach towards the law, anarchist thought - in all its heterogeneous tendencies - is, usually, characterised by a total opposition against the law, which tends to be understood as an irrational, immoral and oppressive 'tool' of the state apparatus that promotes the interests of 
the government against, and not for, its subjects. ${ }^{4}$ The law has the ability to justify the obligation of the people to adhere to the rules of the state and to that extent, it justifies the state's monopoly of violence - "state behaviour is an act of violence, and it calls its violence 'legal right'; that of the individual, "crime," writes Max Stirner $^{5}$ (2017, 209). These views are, famously, echoed by Pierre-Joseph Proudhon when he states: "Laws! We know what they are and what they are worth. Gossamer for the mighty and the rich, fetters that no steel could smash for the little people and the poor, fishing nets in the hands of government" $(2005,90)$. But beyond being an "unworthy hoax" (Bakunin 1964, 136) that justifies and legalises the 'brutish' acts of the state, the law becomes also an insurmountable barrier that fetters any potentiality towards living a life characterised by spontaneity and revolt against hierarchy; and to that extent, it limits and at times terminates the ability of human beings to confront their immanent everyday problems and resolve them according to the particular and singular needs of a situation that they are faced with, without being attached to the commands of the laws of the state or 'enabled' in principle but, simultaneously, hindered in reality. According to Pyotr Kropotkin, people become

perverted by an education which from infancy seeks to kill in [them] the spirit of revolt and to develop that of submission to authority; we are so perverted by this existence under the ferrule of a law, which regulates every event in life - our birth, our education, our development, our love, our friendship - that, if this state of things continues, we shall lose all initiative, all habit of thinking for ourselves. (Kropotkin 1975, 27)

To that extent, people are unable to respond, engage, create and think otherwise because they expect to receive all the answers to their problems from an archist authority of the law of the state, or adapt to the modality that one thing will be valid in the name of a higher abstract principle (in this case law) but another will be valid in everyday reality. ${ }^{6}$

${ }^{4}$ Mikhail Bakunin even suggests that a main characteristic that defines someone as an 'anarchist' is the demand for the absolute abolition of juridical law. As he states in Bakunin 1964, 271: "The Negation of Juridical Law: In a word, we reject all legislation - privileged, licensed, official, and legal - and all authority, and influence, even though they may emanate from universal suffrage, for we are convinced that it can turn only to the advantage of a dominant minority of exploiters against the interests of the vast majority in subjection to them. It is in this sense that we are really Anarchists."

${ }^{5}$ Individualist or egoist, anarchist tendencies, anarcho-nihilists and insurrectionists' affinity to 'illegalism', in the pure sense of the term, is manifested by direct, insurrectional acts against the laws of the state. Such acts are considered by these tendencies to be the only answer to the oppression of the law. For examples of these tendencies and their relation or non-relation to the law, see: Anonymous 2011; Landstreicher 2009; Feral Faun 2010; Serafinski 2016; Bonanno 2009.

${ }^{6}$ The similarity between this view and the way that Deleuze criticises the law is striking. For Deleuze, the law signifies a return to transcendent or archist values, which are uncreative, leading to a fettering and blocking of other possibilities of thinking about and resisting oppression. 
In the remainder of his "Law and Authority" essay, Kropotkin explains how we became so accustomed to obedience and the need for ever-expanding laws that we cannot do without them. Thus, we accept any restraint to our freedom in the name of security, in the name of avoiding what Hobbes understood as the 'threat' of the state of nature, leading to the ultimate pacification of our social and political instincts and the degradation of our spirit of revolt. This leads Kropotkin to suggest that the only viable solution is the total destruction of the juridical system and the law. As he characteristically writes: "No more laws! No more judges! Liberty, equality, and practical human sympathy are the only effectual barriers we can oppose to the anti-social instincts of certain amongst us" (Kropotkin 1975, 43). Despite its invaluable contribution and the ever-pertinent critique of the state of affairs, this 'classical' - if it can be named so - anarchist dismissive approach to law needs to be re-examined and rearticulated if it is to pose an effective nuisance to the mechanisms of domination and the oppression of dogmatism and dominance under an archist mode of being. This is a because, a head-on confrontation with the law and the state - a potential for a general insurrection - does not appear like a pragmatic, or even an effective solution due to the blurry meanings of the law and the state and the overcomplicated relations that characterise our (post)modern societies, including the difficulty of defining and identifying the boundaries of the state and its law. ${ }^{8}$ Perhaps, it is the recognition of this impasse that led, more recently, to the emergence of works that tries to think 'seriously' about the law and its relationship with anarchy in new and interesting ways, including analyses about how questions relating to a living of a life beyond law and the state can be placed in a different sense 'compatible' with an anarchic ethos. ${ }^{9}$ In what follows, I aim to contribute to this discussion by (re)visiting the Deleuzian concepts of the 'institutions' and the nomos of the nomads.

${ }^{7}$ The similarity between Kropotkin's contempt for the judges and the judgmental mode of thinking of the law of the state and Deleuze's appeal not to leave the jurisprudential operation to judges Deleuze is striking $(1995,169)$.

${ }^{8}$ Giorgio Agamben $(1993,84)$ is right when he states in The Coming Community that "the novelty of the coming [here we can add anarchic] politics is that it will no longer be a struggle for the conquest or control of the State, but a struggle between the State and the non-State (humanity), an insurmountable disjunction between whatever singularity and the State organisation." Following this line of thought it could be argue that anarchic politics, if they are to be effective, need to focus more on how to form an ethos that escapes the dogmatic, moralising judgment of the state - of creating new ways of existing that slips away from state's capture. I will support, further, this view in the subsequent sections where I explain Deleuze's use of the term nomos to oppose the law of the state.

${ }^{9}$ See, for example, the works of Lozidiou (2011; 2018; 2019), Newman (2012) and Tamblyn (2019). 


\section{INSTITUTIONS AGAINST THE LAW}

In his first major work, Empiricism and Subjectivity: An Essay on Hume's Theory of Human Nature, Deleuze makes a distinction between the law and institutions. Following, David Hume's critique of the idea of a society based on 'a social contract', Deleuze states that:

The essence of society is not the law but rather the institution. The law, in fact, is a limitation of enterprise and action, and it focuses only on a negative aspect of society. The fault of contractual theories is that they present us with a society whose essence is the law, that is, with a society that has no other objective than to guarantee certain pre-existing natural rights and no other origin than the contract. Thus, anything positive is taken away from the social, and instead the social is saddled with negativity, limitation and alienation. The entire Humean critique of the state of nature, natural rights, and the social contract amounts to the suggestion that the problem must be reversed [...] The institution, unlike the law, is not a limitation but rather a model of actions, a veritable enterprise, an invented system of positive means or a positive invention of indirect means. (Deleuze 1991, 46-47)

In this passage, we observe a distinction between an idea of the law and that of an institution with the first said to be operating as a mere limitation of actions, a restraint. This idea of the law suggests that the people that create 'a society' form - and are formed by - a social contract based on a fundamental sense of law that places restraints on the 'brutish' impulses and passions which would be harmful to the rest of the population in the absence of such a contractual bond, very much akin to Hobbes' views which were noted above. Deleuze, via Hume, argues that a notion of the institution is quite the opposite of the law, in the sense that the institution is something that operates as 'a model of actions' that is characterised by a positive invention and, in that sense, it does not limit action but expands the possibilities of a wider range of actions and responses to the multiplicity of encounters one is faced with each time - the institution is a sort of an enterprise, which is ever-changing, and hence it cannot bind and restrain. Institutions are created in order to "satisfy [their] tendencies and needs"10 (Deleuze 2007, 19) and they are ultimately dissolved or changed if such needs are redundant. Hence, the importance of the distinction between the law and institutions is, for the purposes of this article, that thinking through or with institutions rather than the law, in the sense described above, enables a different perspective about thinking the social, an an-archic way as I shall explain below, which is "profoundly creative, inventive and positive" (Lefebvre 2008, 54).

${ }^{10}$ A parallel line could be drawn between the function of an institution and that of the philosophical concept (Deleuze, Guattari 1994) with the former functioning at a practical level (for example, how to organise in order to respond to a particular, political/social issue) whereas the latter responds to problems of thought. In both situations, however, institutions and concepts are ever-changing and thus, an-archic and non-dogmatic as they do not prioritise any of their parts over the others. 
Despite not expanding further on this distinction, it seems that Deleuze held a fairly consistent approach to it. For instance, in his later book on Leopold von Sacher-Masoch, Coldness and Cruelty, Deleuze states that "laws bind actions; they immobilise and moralise them" $(1991,78)$. To that extent, the law operates through the imposition of certain transcendent or archist action-binding values; classically through the distinction of good and evil, right and wrong, judging actions by hierarchising beings in terms of these actions. In contrast, Deleuze remarks that "pure institutions without laws would by definition be models of free, an-archic action, in perpetual motion, in permanent revolution, in a constant state of immorality"11 (Deleuze 1991, 78, [emphasis added]).

An institution can be said to be envisaged as an open-ended, nomadic space, as I explain below, where we can find each other (The Invisible Committee 2009, 97) and create with each other. It is a way of responding to a particular situation not because we are a priori commanded by archist norms (legal, or moral), but because a situation calls us to create something that is capable to respond to a singular need of the transformation of the social. Further to that, an institution should not operate just as a 'space' where we find each other, but as one where we have the capability of losing each other, of losing or changing the institutions themselves and through our practices - which are never predetermined - losing our own selves and whatever we held as a dogmatic notion of truth and norms. What is meant by that is that an institution is also "an indication of a need for distance, however elastic, temporary, revocable, that is, connected to those that turn out to be the transformations, the metamorphoses, of the social" (Fadini 2019, 528). Thus, we need to always be vigilant for the situation where an institution loses its purpose, or becomes ineffective in responding to the particularities of novel situations. We need to maintain, in other words, the courage to do away with it and to that extent to be able to create something new against convenience, habit or 'common sense' or because its laws and norms dictate that we need to hold on to it even when it stifles life.

In that sense, an institution can be said to hold a paradoxical level of consistency which is determined by a different understanding of how one can operate through an-archic nomoi [vó $\mu \mathrm{ol}$ - if they can be called so - that are not reduced to a hierarchical permanent formation and set finality, since they are to sustain the potency to recreate their rules anew in the present; and as such to reorganise an institution according to the particular needs and uses before a specific and singular circumstance. ${ }^{12}$

We can observe an equation or, at least, a strong resonance between the way Deleuze opposes the law with this notion of the institution. We encounter

${ }^{11}$ Here, perhaps, Deleuze had in mind the work of the French jurist Maurice Hauriou, who thought that the institutions are more important than their laws and contract. This speculation is made by Dosse $(2010,113)$ and Tosel $(2019,145)$.

${ }^{12}$ For a similar view, see: Ford 2016, 94. 
in both an opposition to the dogmatic thinking and moralisation that is promoted by a dominant understanding of the law as a sign of 'progress' of a 'superior civilisation' more generally, with institutions and nomos calling for a creative method of establishing and re-establishing laws and rights which are not reduced to any form of primary, permanent, causes or an archē. Deleuze, explicitly, points towards this relation between an-archic institutions and nomos, when he explains to Toni Negri in the the famous interview, "Control and Becoming" that there is "a whole order of movement in 'institutions' that's independent of both laws and contracts" (Deleuze 1995, 169). Institutions are a matter of a nomos, that has nothing to do with legalistic and dogmatic rules. This nomos becomes, as I explain below, a matter of thinking otherwise about law and our nomic relation to it.

\section{THE $A N$-ARCHIC NOMOS OF THE NOMADS}

In this part, I aim to think beyond the dogmatism of the law by examining a thinking otherwise of the law and the creation of laws and rights, in terms of what Deleuze names nomos. In Difference and Repetition, Deleuze refers to the practice of the distribution in land in its Homeric use as nomos. ${ }^{13}$ While, nomos is widely known as the modern Greek translation of the English word 'law,' according to Deleuze, its Homeric use significantly differs from our understanding of what law is or could be nowadays - "it is a nomos very different from the "law" 14 says Deleuze and Guattari $(1986,16)$. Following the analysis on the meanings of the word by the French linguist Emmanuel Laroche, Deleuze explains that nomos for Homeric society has a pastoral sense. For Deleuze, this meaning of allocation or distribution was not a matter of land distribution, because as the philosopher states the understanding of nomos as land-distribution was "only belatedly implied" (Deleuze 1994, 309). Instead, Deleuze remarks:

Homeric society had neither enclosures nor property in pastures: it was not a question of distributing the land among the beasts but, on the contrary, of distributing the beasts themselves and dividing them up here and there across an unlimited space, forest or mountainside. The nomos designated first of all an occupied space, but one without precise limits (for example, the expanse around a town) - whence, too, the theme of the 'nomad.'(Deleuze 1994, 309)

\footnotetext{
${ }^{13}$ For a brief discussion on that, see: Culp 2016, 56.

${ }^{14}$ I should note here that probably Deleuze's use of nomos relates to the term nomós [voúsc], that "relates to the "distribution-sharing' of land among else, rather than nómos [vó $\mu$ c $]$ as "law." According to Zartaloudis 2019, 140 nomós [vouós] "relates to the family of nemein/nemesthai

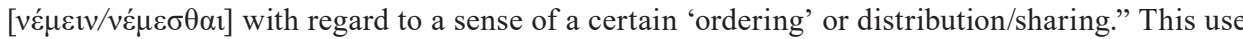
"relates to pasture and herding." Nonetheless, since Deleuze does not distinguish between the two words, for the purposes of this article, I consider just his explanation to see how this understanding of nomos [vó $\mu \mathrm{o}$ ] as a difference sense of 'law' calls us to think otherwise about the law.
} 
Here the figure of the nomad seems to counter the enclosed space - or, striated space in Deleuze and Guattari's terminology - as provided by the official laws of a society based on a so-called 'sophisticated' legal system and rights, for example, a distributor father-figure of a state apparatus or a sovereign.

On the contrary, the nomad, in this particular sense, moves within a smooth space. Deleuze and Guattari crucially explain that 'striated' or 'sedentary' space "is counted in order to be occupied" $(1986,18-19)$ whereas smooth space is "occupied without being counted" $(1986,18)$. This suggests that striated space, faithful to the calculable or metric mentality of the state apparatus and of the law in the sense described earlier, calculates which entities, ideas, rights and modes of life are 'fit' to be included within the enclosed space of its boundaries of rightness and propertyness - according to Deleuze and Guattari, the striated space "measures, puts barriers, borders and hierarchises between insiders and outsiders" (1986, 18-19). This 'calculation' is operated by state's laws and customs which have as a 'measure' the archist morality of the state apparatus and its interests - they act still in accordance with the model of the sovereign, superior and unparticipated 'judgment of God'. ${ }^{15}$ On the other hand, smooth space is a place for creation and invention without a predestined or pre-empted distribution of shares, laws, rights and so forth. It is there to be occupied and moulded accordingly, in order to serve particular needs and respond to a particular situation - the institution, as explained above, corresponds to this understanding of smooth space.

The nomads, as stated above, disorient the authority of the state apparatus and striated space because "such a static or striated formation of identities is insignificant [for them] since their constant movement ensures the dissolution of any form of identity that could supposedly claim any sort of purity" (Deleuze, Guattari 1986, 18-19). Operating within a smooth, boundless space, the nomads are, thus, affiliated with a notion of an an-archic movement without a beginning or end. In that sense, the nomad proceeds in a mode of becoming, in the sense that one refuses to be limited by any form of transcendent, arhcist, moral, fixed or eternal rules, norms and identities - as such, the nomad comes to disorient the conformity of the obedient subject to the state.

According to Deleuze, the nomads follow a nomos which is based on an experience - and not an arche - of a 'nomadic distribution' (Deleuze 1994, 36), which is "a sort of crowned an-archy, that overturned hierarchy [...]" (Deleuze 1994, 41). Similarly to the operation of institutions as opposed to the law, the nomadic distribution functions in an open space that is unlimited, without predetermined beginnings or limited ends. Perhaps, the most distinctive characteristic of the nomads is then that they always try to slip away from the law, the state apparatus, its laws and rights. While, the state always tries to appropriate

${ }^{15}$ See how Deleuze (1998, 126-135) uses Antonin Artaud's work to oppose a transcendent, judgmental mode of being. 
nomadic creativity - presenting it even as 'entrepreneurship', 'innovation' and 'progress' the nomads must remain vigilant and find the line of flight to escape capture, and to continue to live in a creative an-archic space. ${ }^{16}$ Thus, even though the an-archic distribution of the nomads may, often, appear to be 'captured' within the dogmatism of law and the state apparatus, this is not the case according to Deleuze and Guattari:

even though the nomadic trajectory may follow trails or customary routes, it does not fulfil the function of the sedentary road, which is to parcel out a closed space to people, assigning each person a share and regulating the communication between shares. The nomadic trajectory does the opposite: it distributes people (or animals) in an open space, one that is indefinite and non-communicating. The nomas came to designate the law, but that was originally because it was distribution, a mode of distribution. It is a very special kind of distribution, one without division into shares, in a space without borders or enclosure. The nomas is the consistency of a fuzzy aggregate: it is in this sense that it stands in opposition to the law or the polis, as the backcountry, a mountainside, or the vague expanse around a city ("either nomos or polis"). (Deleuze, Guattari 1986, 50-51)

The nomos of the nomads, their distribution into space, paves the way for a necessarily non-juridical understanding of a non-law since it escapes the narrow pre-set boundaries of juridicalised hierarchy and juridical dogmatism. It is in that sense an-archic "akin to a dispersal [but] somewhat orderly" (Zartaloudis $2019,142)$. Akin perhaps to the way a particular logic used in, say, mapping a geographical territory determines also what one sees (or not). Just like the unmapped chaos that accompanies becoming and pure immanence, the map of a nomadic distribution is possible as it is still 'consistent' in its an-archy, and that enables it to expose the archist-infused law's blackmail of the supposedly catastrophic results in the absence of an arche. The mapping of the laws-map is a 'sham' that permits the eternalisation of the pacifying domination in the form of rules disguising the a priori necessitated distinction between the 'masters' and the 'subordinates' and the ways in which they can each pragmatically 'exercise' their rights.

${ }^{16}$ See: Deleuze, Guattari 1986, 22-30. Deleuze and Guattari explain how the state apparatus tries to appropriate nomadic science, incorporating into its royal (calculable) science. See also: Châtelet 2014, esp. chapter 6. Châtelet explains how the market promotes the image of a flexible 'nomad' which seeks innovation and movement, all, of course, in order to serve the politics of the market. The nomad of the market is, often, the precarious, or worse, employed or unemployed who in the name of 'innovation' and fluidity is always vulnerable to any sort of exploitation. As Châtelet (2014), 75 writes: "Young nomads we love you! Be yet more modern, more mobile, more fluid, if you don't want to end up like your ancestors in the muddy fields of Verdun. The Great Market is your draft board! Be light, anonymous, precarious like drops of water or soap bubbles: this is true equality, that of the Great Casino of life! If you're not fluid, you will very quickly become losers. You will not be admitted into the Great Global Super Boom of the Great Market... Be absolutely modern (like Rimbaud), be a nomad, be fluid - or check out, like a viscous loser!" 
An an-archic nomos is, then, an ethico-political action that aims to break the boundaries of the dogmatic mode of thinking and existing that is promoted with the law, a supposedly archist morality re-establishing the primacy of a concrete notion of identity, as opposed to the constant movement of becoming. ${ }^{17}$ It is a way to expose and to "disturb the state and the law from the outside" (Newman 2012, 327). In that sense, it is in a constant opposition and strife against the dogmas and hierarchies of any state apparatus, and it should be ready to respond adequately to any assault coming from them. It has to possess a lethal instinct ready to destroy any form of dogmatism and 'break the wheel' of the 'current state of affairs' (of what also leads one to say what they think but then also say 'yet, at the end of the day...'), refusing to compromise and to be 'pacified' by any call for pseudo-progress and consensusualism. ${ }^{18}$

Such a nomos is an-archic because it refuses to be subordinated by any form of pre-emptive hierarchising, and it refuses to prioritise a mode of being over another. Despite its anarchy, however, a nomos remains within its own consistency, in the sense that it functions by '(re)organising' itself through institutions, or through what we can call nomoi, that are ever-changing and expressive (as opposed to representative) of a certain situation in question. Its ethos is anarchic, because it operates through a mode of immanent being that does not rely on dogmatic, archist values, laws and rights. It is rather an immanent autonomous ethos, because since anyone who operates through this an-archic ethos is the cause and the consequence of the operation (or perhaps causes and consequences become so blurry that are no more). This is perhaps the heart of the creativity that can be found in the an-archic persona of the nomad who wants "to become worthy of what happens to [it], [...] to become the offspring of one's own events, and thereby to be reborn, to have one more birth, and to break with one's carnal birth [...]" (Deleuze 2015, 149). Similarly to what Deleuze and Guattari define as becomingdemocratic, ${ }^{19}$ we can talk in this manner of a becoming-law or a becoming-right in this life where its 'essence' and its praxis are indissociable and it is this threshold that forms its ethos. A becoming-law or a becoming-right does not have anything

\footnotetext{
${ }^{17}$ For a brief discussion on the becoming of the nomads see: Sellars 2007, 34-35.

${ }^{18}$ I am using here lethal and 'destruction' in similar terms to Benjamin 1986, esp. 297.

${ }^{19}$ Deleuze and Guattari (1994, 113): "A becoming-democratic that is not the same as what
} States of law are, or even a becoming-Greek that is not the same as what the Greeks were. The diagnosis of becomings in every passing present is what Nietzsche assigned to the philosopher as physician, 'physician of civilization,' or inventor of new immanent modes of existence. Eternal philosophy, but also the history of philosophy, gives way to a becoming-philosophical. What becomings pass through us today, which sink back into history but do not arise from it, or rather that arise from it only to leave it? The Aternal, the Untimely, the Actual are examples of concepts in philosophy; exemplary concepts." Here, Deleuze and Guattari clarify that a 'becoming-something' does not resemble the 'final' or 'identarian' form of this or that 'something' but, instead, its becomings hide a multiplicity of other potentialities that can be explored in perpetuity in order to form something new. 
to do with imitating any kind of supposedly progressive or 'civilising' human behaviour, or equally with betraying a 'principle,' or, indeed, with assimilating into a certain set ordering by once more attempting to impose itself on others (like the many such attempts promoted also through or in the name of/or against the law, laws and rights in order to rebuild soon to be again 'civilised' state apparatuses).

This becoming, at a 'personal' level (though one that can no longer be labelled as such), is an ability to be attentive and open to what happens to us, to be able to appreciate and to be feasibly curious (and thus ready to let ourselves go and forget our certainties ${ }^{20}$ ) in order to live with the (un)known. Perhaps, one does so by embracing key characteristics, which define the radical ascetic virtue of all great philosophers, and which are, according to Deleuze, 'humility', 'chastity' and 'poverty' (Deleuze 2001, 3). It is through these fundamental but lived virtues that we are ready to accept and become worthy of the situations and cases that we are faced with - and this ability of becoming worthy of oneself is at the very heart of an an-archic ethos. In other words, not to be split between an ideal self (who believes in, say, the law) and a real self (who is unable to make ends meet or be equal to others).

To that extent, our failures are not to be any longer the source of renewed ressentiment and our success not a matter of the arrogance of accumulation and progress. Instead, failure and success are closely connected and are accepted as some of the many immanent possibilities of living. A life with this an-archic nomos then is able to accept and embrace its limits and 'the exhaustion of possibilities', that will make the strife begin anew, rather than fall back into the 'tiredness' that bolsters ressentiment, dogmatism and archism. ${ }^{21}$ For this reason, everything is harder and yet more sustainable among ourselves.

\section{BIBLIOGRAPHY}

Agamben, Giorgio. 1993. The Coming Community. Translated by Michael Hardt. Minneapolis: University of Minnesota Press.

Agamben, Giorgio. 2019. Creation and Anarchy: The Work of Art and Religion of Capitalism. Translated by Adam Kotsko. Stanford CA: Stanford University Press. https://doi org/10.1515/9781503609273

Anonymous. 2011. Enemies of Society: An Anthology of Individualist and Egoist Thought. San Francisco: Ardent Press.

Bakunin, Mikhail. 1964. The Political Philosophy of Bakunin: Scientific Anarchism. Translated and Edited by G.P. Marximoff. New York: The Free Press of Glencoe.

Benjamin, Walter. 1986. "Critique of Violence." Translated by Edmund Jephcott. In Reflections: Essays, Aphorisms, Autobiographical Writings. 277-300. Edited by Peter Demetz. New York: Schocken Books.

${ }^{20}$ Caroll $(2015,15)$ : “'Curiouser and curiouser!' Cried Alice (she was so much surprised, that for the moment she quite forgot how to speak good English."

${ }^{21}$ For the difference between 'exhaustion' and 'tiredness' see: Deleuze 1998, 152-174. 
Bonanno, Alfredo M. 2009. Insurrectionalist Anarchism: Part One. Translated by Jean Weir. London: Elephant Editions.

Caroll, Lewis. 2015. The Complete Alice. Basingstoke: Macmillan Children's Book.

Châtelet, Gilles. 2014. To Live and Think Like Pigs: The Incitement of Envy and Boredom in Market Democracies. Translated by Robin Mackay. New York: Sequence Press.

Colson, Daniel. 2019. A Little Philosophical Lexicon of Anarchism: From Proudhon to Deleuze. Translated by Jesse Cohn. New York: Minor Compositions.

Culp, Andrew. 2016. Dark Deleuze. Minneapolis: University of Minnesota Press. https://doi. org/10.5749/9781452958392

Deleuze, Gilles. 1991. Empiricism and Subjectivity: An Essay on Hume's Theory of Human Nature. Translated by Constantin V. Boundas. New York: Columbia University Press.

Deleuze, Gilles. 1991. Masochism: Coldness and Cruelty. Translated Jean McNeil. New Jersey: Zone Books.

Deleuze, Gilles. 1994. Difference and Repetition. Translated by Paul Patton. New York: Columbia University Press.

Deleuze, Gilles. 1995. Negotiations. Translated by Martin Joughin. New York: Columbia University Press.

Deleuze, Gilles. 1998. Essays Critical and Clinical. Translated by Daniel Smith, Michael Greco. London-New York: Verso.

Deleuze, Gilles. 2001. Spinoza: Practical Philosophy. Translated by Robert Hurley. San Francisco: City Lights Publishers.

Deleuze, Gilles. 2007. Two Regimes of Madness: Essays and Interviews 1975-1995. Translated by Ames Hodges, Mike Taormina. Los Angeles CA: Semiotext(e).

Deleuze, Gilles. 2015. Logic of Sense. Translated by Constantin V. Boundas, Mark Lester, Charles J. Stivale. London: Bloomsbury.

Deleuze, Gilles. Félix Guattari. 1986. Nomadology: The War Machine. Translated by Brian Massumi. Los Angeles CA: Semiotext(e).

Deleuze, Gilles. Félix Guattari. 1994. What Is Philosophy?. Translated by Graham Burchell, Hugh Tomlinson. London-New York: Verso.

Dosse, François. 2010. Deleuze and Guattari: Intersecting Lives. Translated by Deborah Glassman. New York: Columbia University Press.

Fadini, Ubaldo. 2019. "Deleuze's Notion of The Institution: In A Direction of Different Distance." Deleuze \& Guattari Studies 13(4): 528-540. https://doi.org/10.3366/dlgs.2019.0378

Feral Faun. 2010. Feral Revolution. London: Elephant Editions.

Ford, Russell. 2016. "Humor, Law and Jurisprudence." Angelaki 21(3): 89-102. https://doi.org/10. 1080/0969725X.2016.1205263

Gray van Heerden, Chantelle. Aragorn Eloff. Eds. 2019. Deleuze and Anarchism. Edinburgh: Edinburgh University Press. https://doi.org/10.3366/edinburgh/9781474439077.001.0001

Hobbes, Thomas. 1986. Leviathan. London: Penguin Classics.

Kropotkin, Pyotr. 1975. "Law and Authority." In The Essential Kropotkin. 27-43. Edited by Emile Capouya, Keitha Tompkins. London: Palgrave Macmillan. https://doi.org/10.1007/978-1-34902959-4 3

Landstreicher, Wolfi. 2009. Willful Disobedience. San Francisco: Ardent Press.

Lefebvre, Alexandre. 2008. The Image of Law: Deleuze, Bergson, Spinoza. Stanford CA: Stanford University Press.

Loizidou, Elena. 2011. "This Is What Democracy Looks Like.” In How Not To Be Governed: Readings And Interpretations From A Critical Anarchist Left. 167-187. Edited by Jimmy Class Clausen, James Martel. New York: Rowman \& Littlefield International. 
Loizidou, Elena. 2018. "Love, Law, Anarchy." In Law and Philosophical Theory: Critical Intersections. 167-182. Edited by Thanos Zartaloudis. New York: Rowman \& Littlefield International.

Loizidou, Elena. 2019. "What is Law?" In Anarchist Imagination: Anarchism Encounters the Humanities and the Social Sciences. 181-193. Edited by Carl Levy, Saul Newman. London: Routledge. https://doi.org/10.4324/9781315693163-11

Newman, Saul. 2012. "Anarchism and Law: Towards a Post-Anarchist Ethics of Disobedience." Griffith Law Review 21(2): 307-329. https://doi.org/10.1080/10383441.2012.10854742

Proudhon, Pierre-Joseph. 2005. "The Authority Principle.” In No Gods, No Masters: An Anthology of Anarchism. 81-98. Edited by Daniel Guerin, Paul Sharkey. Edinburgh: AK Press.

Schmitt, Carl. 2006. The Nomos of the Earth: in the International Law of the Jus Publicum Europaeum. Translated by G.L. Ulmen. New York: Telos Press Publishing.

Sellars, John. 2007. "Deleuze and Cosmopolitanism." Radical Philosophy 142: 30-37.

Serafinski. 2016. Blessed is the Flame: An Introduction to Concentration Camp Resistance and Anarcho-nihilism. Berkeley CA: Little Black Cart.

Stirner, Max. 2017. The Unique and Its Property. Translated by Wolfi Landstreicher. Middletown DE: Underworld Amusements.

Tamblyn, Nathan. 2019. "The Common Ground Between Law and Anarchism." Law Review 40: 65-78. https://doi.org/10.1007/s10991-019-09223-1

The Invisible Committee. 2009. The Coming Insurrection. Los Angeles CA: Semioetext(e).

Tiqqun. 2010. Introduction to Civil War. Translated by Alexander R. Galloway, Jason E. Smith. Los Angeles CA: Semiotext(e).

Tosel, Natascia. 2019. "Anarchy and Institution: A New Sadean Possibility." In Deleuze and Anarchism. 136-154. Edited by Chantelle Gray van Heerden, Aragorn Eloff. Edinburgh: Edinburgh University Press. https://doi.org/10.3366/edinburgh/9781474439077.003.0009

Zartaloudis, Thanos. 2019. The Birth of Nomos. Edinburgh: Edinburgh University Press. https://doi. org/10.3366/edinburgh/9781474442008.001.0001 